\title{
A (im)parcialidade do Magistrado: breve análise do instituto do Juiz de Garantias à luz do pacote anticrime
}

\author{
The (im)partiality of the Magistrate: brief analysis of the \\ Guarantee Judge Institute in the light of the anticrime package
}

\author{
Thiago Trindade de Almeida \\ Emerson da Silva Mendes ${ }^{2}$ \\ Fabio da Silva Bozza ${ }^{3}$
}

\begin{abstract}
RESUMO
$\mathrm{O}$ presente trabalho objetiva discutir, à luz das garantias constitucionais, as recentes modificações ocorridas no Código Processual Penal (Decreto-lei $\mathrm{n}^{\circ} 3.689 / 41$ ) a partir da Lei $\mathrm{n}^{\circ}$ 13.964/19, conhecida popularmente como "Pacote Anticrime", no que concerne ao Instituto do Juiz das Garantias. Para tanto, recorre-se, enquanto procedimento metodológico, à revisão bibliográfica de cunho qualitativo. Desse modo, o corpus foi constituído a partir da análise da normativa vigente, bem como da doutrina, da jurisprudência e de julgados dos Tribunais Superiores. Sustenta-se a necessária inserção do juiz das garantias no ordenamento jurídico e no rito processual penal, com a finalidade de desvincular a atuação do magistrado nas duas fases do processo, bem como garantir a imparcialidade do juiz e a decisão tomada sob provas suscetíveis ao contraditório, garantindo, dessa forma, o devido processo legal, justo e imparcial, respeitando os limites do Estado e da magistratura, tutelando, com maior eficiência, a parte mais vulnerável nessa relação processual, o acusado.
\end{abstract}

\section{PALAVRAS-CHAVE:}

Juiz das Garantias, Direitos e Garantias Fundamentais, Princípios Constitucionais, Pacote AntiCrime.

\footnotetext{
ABSTRACT

This paper aims to discuss in the light of constitutional guarantees recently changes that have ocurred in the Criminal Procedural Code (Decree-Law n. 3.689/41) from to Law n. ${ }^{\circ}$ 13.964/19 - popularly known as the "Antcrime Package". This law regard to the Institute of The Judge of Guarantees. The methodological procedure used by this paper is a qualitative literature review. The project it was constituted from the analysis of the current normas as well as the doctrine jurisprudence and juges of the Superior Courts. The necessary insertion of the judge of

${ }^{1}$ Graduando no Curso de Bacharelado em Direito pela Universidade Federal do Sul da Bahia (UFSB). Bacharel em Humanidades pela Universidade Federal do Sul da Bahia (2018). Membro do Grupo de Pesquisa e Extensão em Pluralismo Jurídico e Usos Emancipatórios do Direito.

2 Discente do curso de Pós-Graduação Lato Sensu em Gênero e Sexualidade na Educação pela Universidade Federal da Bahia (UFBA), Graduando no Curso de Bacharelado em Direito pela Universidade Federal do Sul da Bahia (UFSB), Bacharel Interdisciplinar em Humanidades pela Universidade Federal do Sul da Bahia (2017). Membro do Grupo de Pesquisa e Extensão em Pluralismo Jurídico e Usos Emancipatórios do Direito.

${ }^{3}$ Professor Adjunto na Universidade Federal do Sul da Bahia (UFSB), Doutor em Direito do Estado (2014) e Mestre em Direito das Relações Sociais (2006) pela Universidade Federal do Paraná (UFPR), Bacharel em Direito pela Faculdade de Direito de Curitiba (2003).
} 
guarantees in the legal order and the criminal procedural rite is upheld with the purpose of untying the magistrate's perfomance in the two phases of proceendind as well as ensuring the impartiality of the judge and the decision taken under evidence susceptible to contradictory. This Institute guarantees the fair and impartial due process respecting the limits of the State and the judiciary power. The Judge of guarantees will keep more effective the most vulnerable part in this procedural relationship - the accused.

\section{KEYWORDS:}

Judge of Guarantees, Fundamental Rights and Guarantees, Constitutional Principles, AntiCrime Package.

\section{INTRODUÇÃO}

Até a reforma do Código de Processo Penal, oriunda da Lei. n 13.964/2019 (conhecida como Pacote Anti Crime), o Juiz que teria acesso à fase pré-processual (ou investigativa), antes do recebimento da denúncia, seria prevento para fase processual, cabendo a ele decidir sobre o caso. Tal procedimento, no entanto, ocasionou em debates doutrinário a respeito da violação do princípio da imparcialidade do juiz, sendo, posteriormente, objeto de inúmeras decisões, quanto ao prejuízo dos direitos do acusado, pelo Tribunal Europeu de Direitos Humanos e significativas mudanças legislativas em alguns países europeus e latino-americanos (como no Chile, na Espanha, na Itália, entre outros).

Nesse sentido, surge o instituto do Juiz das Garantias, como forma de garantir uma maior imparcialidade na atuação do magistrado, bem como proporcionando um processo penal democrático e genuinamente acusatório, sem prejuízo de consequências como a formulação de pré-julgamentos que, possivelmente, poderiam contaminar a sentença final à determinado caso em concreto.

Visto isso, o presente trabalho possui como objetivo principal a investigação sobre a figura do Juiz das Garantias e sua imprescindibilidade para o processo penal brasileiro, como meio de garantir a separação da atuação do juiz em sede do inquérito policial (fase préprocessual) e em sede de julgamento (fase processual). Essa separação possibilita a devida 
imparcialidade do juiz na tomada de decisões e a permanência da figura do juiz como garantidor dos direitos fundamentais do cidadão.

Quanto à metodologia, o presente trabalho estruturou-se por meio da revisão bibliográfica a respeito do sistema processual penal brasileiro e do instituto do juiz das garantias, com a finalidade de realizar “[...] um apanhado geral sobre os principais trabalhos já realizados, revestidos de importância, por serem capazes de fornecer dados atuais e relevantes relacionados com o tema” (MARCONI e LAKATOS, 2002, pág. 158).

Do ponto de vista teórico metodológico, o trabalho será conduzido na perspectiva da pesquisa exploratória qualitativa, pois em um primeiro momento, este se mostra como um adequado mecanismo para a presente propositura, permitindo derivar da referida amostra aspectos de cunho qualitativo, sendo este imprescindível para se compreender o objeto em sua plenitude e, imerso em seu contexto, de forma a não excluir quaisquer elementos de subjetivação ou outros importantes para o presente feito. Acerca do método qualitativo, pondera Minayo (2001, pág 15), que “[...] o objeto das Ciências Sociais é essencialmente qualitativo. A realidade social é o próprio dinamismo da vida individual e coletiva com toda a riqueza de significados dela transbordante".

Desse modo, a presente pesquisa desenvolveu-se através da revisão bibliográfica e documental, realizada por meio de fontes primárias (Lei nº 13.964/2019), secundárias (manuais, artigos, obras literárias, e outros) e terciárias (bibliografias de bibliografias), objetivando a potencialização da exploração de novos argumentos, a partir de pressupostos teóricos a respeito do tema, de forma que esse novo panorama de abordagem possa contribuir para o conhecimento e aplicação do novo instituto, não possuindo, como finalidade, o exaurimento dos diálogos relacionados ao tema.

\section{O PROCESSO PENAL E OS SISTEMAS PROCESSUAIS PENAIS: BREVES CONSIDERAÇÕES.}

O processo penal é um instrumento legitimador da atuação do poder de penar do Estado. Além disso, constitui processo garantidor de direitos fundamentais do acusado, na observância de diversas regras que compõem o devido processo legal. Segundo Aury Lopes Jr. (2018, pág. 
33), o liame entre a pena e o processo penal corresponderia ao princípio da necessidade, segundo o qual “[...] o processo penal é um caminho que condiciona o exercício do poder de penar (essência do poder punitivo) à estrita observância de uma série de regras que compõe o devido processo legal".

Dentre os sistemas processuais penais existente nos países destacam-se dois: o sistema inquisitório e o sistema acusatório. Quanto ao primeiro, proveniente do século XII, nasce influenciado, principalmente, pelos ditames da Igreja Católica, no então conhecido Tribunal Inquisitorial. Contudo, acerca desse sistema, Aury Lopes Jr. (2019, pág. 46), pontua que o “[...] sistema inquisitório foi desacreditado - principalmente - por incidir em um erro psicológico: crer que uma mesma pessoa possa exercer funções tão antagônicas como investigar, acusar, defender e julgar".

Em contrapartida, quanto ao sistema acusatório, foi o primeiro sistema processual na história da civilização, pois, na época anterior a Idade Média (e antes da dominação da Igreja), as acusações eram feitas por particulares, sendo decididas por um terceiro imparcial (muitas vezes o rei da tribo ou do reino), alheio à vontade das partes, não guardando vinculação entre a acusação e os interesses do Estado.

Assim, diante de tal distinção, destaca Aury Lopes Jr. (2019, pág. 48) que “o processo penal acusatório caracteriza-se, portanto, pela clara separação entre juiz e partes, que assim deve se manter ao longo de todo o processo". Logo, o sistema acusatório, em seu caráter primitivo, foi o sistema fundante, visto que não havia uma polícia, nem Estado-Nação configurado e um princípio de organização social, distribuído em feudos, sendo necessária a intervenção do suserano nos conflitos entre seus vassalos.

Após esse rompimento sistemático e a inserção do modelo inquisitorial, houve um desenvolvimento do processo penal e, principalmente, quanto à produção de provas, que antes eram imperfeitas e sem técnica e, posteriormente, passa a ter alguns contornos científicos para o devido inquérito. Nesse momento, o Direito passa a influenciar a ciência e a forma de como se chegar a verdade (LOPES JR., 2019). Assim, abre-se espaço para uma filosofia da consciência, na busca por uma verdade real (absoluta e intolerante) por meio da razão e das técnicas procedimentais. Uma razão que passa a ser influenciada, decisivamente, por uma verdade que se busca chegar através de uma razão técnico-instrumental. 
Feito um breve esboço acerca dos sistemas processuais penais, faz-se necessário expor a influência desses modelos no ordenamento jurídico brasileiro. Antes da Constituição de 1988, havia um processo judicialiforme, caracterizado por: a) uma gestão de provas realizada pelo juiz; b) buscava-se uma verdade real; c) o juiz era um inquisitor; d) a valoração da prova era orientada pelo sistema de tarifação das provas, o qual cada prova possui um grau de hierarquia, sendo a confissão a rainha das provas; e e) uma ampla liberdade processual para o juiz.

Após a Constituição e a configuração do Estado Democrático de Direito, o Brasil acaba adotando um modelo de sistema acusatório, característico por: a) um juiz imparcial; b) uma separação e interdependência entre os órgãos atuantes no processo penal; c) um necessário direito ao contraditório; d) valoração da prova orientada pelo sistema do livre convencimento motivado; e) e uma publicidade dos processos, salvo quando necessária a preservação da pessoa (por exemplo, quando envolve crianças e/ou adolescentes).

No entanto, questiona-se se o sistema acusatório, modelo normativo determinado pela Constituição Federal e pela forma de Estado Democrático de Direito, funciona, na prática judicial, como filtro interpretativo das normas infraconstitucionais, em especial no que se refere à gestão das provas, iniciativa em matéria de medidas cautelares e sentença.

\section{A (IM)PARCIALIDADE DO JUIZ DO PROCESSO PENAL BRASILEIRO: A VIOLAÇÃO DE PRINCÍPIOS CONSTITUCIONAIS PELA LEGISLAÇÃO INFRACONSTITUCIONAL.}

O processo penal - entendido como percurso para alcançar a pena e elemento condicionante ao exercício do poder de penar -, em um sistema constitucional, prevê uma observância e, diante disso, um sistema imprescindível de garantias mínimas ao acusado. Esse sistema corresponde ao“núcleo conceitual do princípio da necessidade do processo penal, garantindo direitos fundamentais e legitimando a imputação da pena.

Diante disso, o objeto do processo penal é uma pretensão acusatória, composta por um caso penal (fato aparentemente ilícito), sujeitos (tanto aquele que exerce a pretensão de acusar 
como aquele que pretende fazer valer a pretensão) e a atividade de declaração da propositura de ação estatal. Dentre esses elementos, há regras que devem ser respeitadas e procedimentos a serem seguidos.

Logo, para Aury Lopes Jr. (2018, pág. 57), “a função do juiz é atuar como garantidor dos direitos do acusado no processo penal". Além disso, o autor complementa que, no Estado Democrático de Direito, a figura do magistrado vai além de mera atuação política. Constituise, portanto, como garantidor ${ }^{4}$ da aplicabilidade e da intangibilidade dos direitos fundamentais, aplicando o direito segundo o respeito às garantias fundamentais e devidamente fundamentadas.

Ainda sobre a relação processual, Bueno de Carvalho (2001, pág. 56) esclarece que a lei é o limite à dominação. Logo, a pretensão da lei consubstancia-se na proteção ao mais débil da relação (lado mais vulnerável da relação). Em relação ao processo penal, a identificação do vulnerável não caracteriza-se na vítima, mas sim no acusado, frente ao poder de penar do Estado. Neste ponto, faz-se imprescindível o papel do juiz como garantidor dos direitos. Além disso, o juiz "[...] deve tutelar o indivíduo e reparar as injustiças cometidas e absolver quando não existirem provas plenas e legais" (AURY. 2018, pág. 59).

Ter um juiz imparcial, natural e comprometido com a máxima eficácia da Constituição é pressuposto balizante para o processo penal em um Estado Democrático de Direito. O juiz independente, neste caso, seria alguém, dotado de pleno conhecimento jurídico, que realmente possua livres condições de tomar sua convicção, longe de interferências políticas externas ou outros fatores (ALMEIDA, 2019, s/p).

Dessa maneira, o juiz teria plenos poderes, dentro dos limites e liames da instrumentalidade constitucional do processo, de dar prosseguimento ao rito processual penal, no intuito de solucionar o fato legitimante da propositura da ação penal, tutelando o indivíduo e reparando as injustiças que porventura vierem a ser conhecidas por meio dos elementos probatórios.

Além disso, a imparcialidade do magistrado é imprescindível ${ }^{5}$ na tomada de decisão, mesmo se for contrária à opinião da maioria. É necessário que o juiz atue alheio aos interesses das partes e esteja respaldado, em sua decisão, única e exclusivamente em instrumentos com

\footnotetext{
${ }^{4}$ Segundo Aury Lopes Jr. e Ruiz Ritter (2016, pág. 57), o juiz deve atuar como garante dos direitos fundamentais do sujeito passivo, quando este for convocado a se fazer presente no inquérito policial.

${ }^{5} \mathrm{O}$ princípio da imparcialidade do juiz é elemento fundante e princípio supremo do processo. Este é imprescindível para o bom andamento do caso em análise e do seu posterior julgamento.
} 
força probatória submetidos ao contraditório e ampla defesa de quem está sendo acusado. Diferentemente do que ocorre com o juiz-ator, típico de um sistema inquisitorial, o qual "destrói a estrutura dialética do processo penal, o contraditório, a igualdade de tratamento e oportunidade e, por derradeiro, a imparcialidade” (AURY, 2018, pág. 63).

Logo, no sistema acusatório, o juiz não tem função investigatória, tampouco pode produzir provas, pois, do contrário, estaria prejudicada sua imparcialidade ${ }^{6}$. A inércia é o que caracteriza a atividade judicial.

No entanto, no rito procedimental do processo penal brasileiro, há elementos ${ }^{7}$ que expõe a imparcialidade do juiz à prova. De acordo com os ensinamentos de Aury Lopes Jr. (2018, pág. 64):

A imparcialidade do juiz fica evidentemente comprometida quando estamos diante de um juiz-instrutor (poderes investigatórios) ou quando lhe atribuímos poderes de gestão/iniciativa probatória. É um contraste que se estabelece entre a posição totalmente ativa e atuante do instrutor, contrastando com a inércia que caracteriza o julgador. Um é sinônimo de atividade, e o outro, de inércia.

Visto isso, dedica-se, então, às exceções inquisitoriais positivadas no ordenamento jurídico, que causam uma inerente violação à jurisdicionalidade e à imparcialidade do juiz no processo penal.

Segundo dispõe o artigo 156 do Código de Processo Penal (CPP),

Art. 156 - A prova da alegação incumbirá a quem a fizer, sendo, porém, facultado ao juiz de ofício:

I - ordenar, mesmo antes de iniciada a ação penal, a produção antecipada de provas consideradas urgentes e relevantes, observando a necessidade, adequação e proporcionalidade da medida;

II - determinar, no curso da instrução, ou antes de proferir sentença, a realização de diligências para dirimir dúvida sobre ponto relevante.

Percebe-se, portanto, a atuação ativa do juiz na primeira fase da persecução penal, podendo este, de ofício, determinar a produção de provas quando achar conveniente ao

\footnotetext{
${ }^{6} \mathrm{O}$ magistrado, quando solicitado para atuar em fase pré-processual, possui como função, pura e simplesmente, de controlador da legalidade dos atos investigatórios e de garantidor dos direitos fundamentais (este último não apenas na fase pré-processual mas em todo a persecução penal). Uma atuação para além desses limites, portanto, acabaria por violar o princípio da imparcialidade, desvinculando-se da postura suprapartes que o juiz deve ter no processo penal (LOPES JR. e RITTER, 2016, pág. 57).

${ }^{7}$ Há, no ordenamento jurídico brasileiro, dispositivos normativos que possibilitam a atuação, de ofício ou a requerimento do Ministério Público, do magistrado em fase pré-processual. Essa atuação acaba por mexer na inércia e no caráter suprapartes do juiz, significando uma mudança completa de características do sistema processual, possibilitando ações de caráter inquisitório e autoritário.
} 
processo, tanto para antecipação de provas consideradas urgentes, quanto para dirimir possíveis dúvidas sobre pontos relevantes. É o que defende Aury Lopes Jr. (2018, pág. 64), quando, a respeito do mencionado artigo, salienta que "[...] o art. 156 do CPP funda um sistema inquisitório, pois representa uma quebra da igualdade, do contraditório, da própria estrutura dialética do processo. Como decorrência, fulminam a principal garantia da jurisdição, que é a imparcialidade do julgador".

Ora, se é permitido ao julgador produzir provas para dirimir dúvidas sobre pontos relevantes, sua imparcialidade está comprometida. De acordo com o princípio da presunção de inocência, a dúvida impõe uma decisão absolutória. Se o magistrado pretende afastar sua dúvida, tal ato só pode ser considerado como inclinação para condenação, já que a dúvida impõe a absolvição.

Não obstante, nos termos do Art. 310, II, do CPP, ao juiz também lhe é facultada a conversão da prisão em flagrante em prisão preventiva, antes mesmo do oferecimento da denúncia.

Não apenas nesses dois pontos são vistos indícios de um sistema inquisitório, de modo a se evidenciar a possível parcialidade do juiz: a) no artigo 212 do CPP, quanto às perguntas direcionadas às testemunhas, "não admitindo o juiz aquelas que puderem induzir a resposta, não tiverem relação com a causa ou importarem na repetição de outra já respondida"; b) em fase de instrução criminal, o artigo 404, caput, do CPP, prevê a possibilidade de o juiz, de ofício, concluir a audiência sem as alegações finais, quando as diligências forem consideradas imprescindíveis; c) ou, até mesmo, em fase de sentença, previsto no artigo 385 do CPP, quando, "nos crimes de ação pública, o juiz poderá proferir sentença condenatória, ainda que o Ministério Público tenha opinado pela absolvição, bem como reconhecer agravantes, embora nenhuma tenha sido alegada".

As situações acima mencionadas representam transgressões ao princípio da imparcialidade do magistrado, maculando o sistema acusatório, característico do Estado Democrático, e abrindo espaço para atividades inquisitoriais ${ }^{8}$. Portanto, diante de tais

\footnotetext{
${ }^{8}$ A atuação na fase pré-processual do juiz, na atual conjectura processual brasileira, pode acabar por ocasionar dois grandes problemas: a) uma postura inquisitória, sendo determinante para produção antecipada de provas, por exemplo; b) e a condução de pré-julgamentos (ou pré-juízos), causando um prejuízo cognitivo, principalmente à
} 
circunstâncias, deve-se reconhecer como positiva a alteração legislativa produzida pela Lei $\mathrm{n}^{\circ}$ 13.964/2019 (Pacote Anticrime), segundo a qual verifica-se a desvinculação das atividades judiciais a serem realizadas na fase pré-processual (inquérito policial) e fase processual (oriunda do recebimento da denúncia), situação em que, realmente, se terá um processo com juiz imparcial (não influenciado por fatores não postos em contraditório e que possam interferir no julgamento futuro) no qual são observados os direitos ao contraditório e à ampla defesa. Para isso, necessário se faz a implantação do juiz das garantias, como medida lógica para proteção dos direitos fundamentais do acusado.

\section{A FIGURA DO JUIZ DAS GARANTIAS NO PROCESSO PENAL BRASILEIRO: ELEMENTO NECESSÁRIO PARA O DEVIDO PROCESSO LEGAL E AO RESPEITO DOS DIREITOS FUNDAMENTAIS DO ACUSADO.}

O Processo Penal brasileiro, na dimensão das normas infraconstitucionais, como vimos, está pautado num sistema acusatório com indícios inquisitivos, onde o mesmo magistrado atua na fase pré e pós-processual, bem como possui a possibilidade de uma intervir ativamente no processo, como, por exemplo, na produção de provas e na oitiva de testemunhas. Essa postura ativa do judiciário, portanto, acaba por macular o princípio da imparcialidade do juiz, aumentando a vulnerabilidade do acusado frente ao poder punitivo do Estado.

Frente ao cenário posto, o Projeto de Lei 156/2009, de autoria do então Senador José Sarney, arquivado no ano de 2018, objetivava uma reforma no Direito Penal (Decreto-lei $\mathrm{n}^{\circ}$ 2.848/40 e Código Processual Penal - Decreto-lei nº 3.689/41), inserindo, no cenário normativo, o juiz das garantias no processo penal. O referido instituto, portanto, possibilitaria uma separação da atuação "[...] do magistrado nos dois procedimentos acima citados e permitindo uma atuação mais alinhada a um processo penal democrático consubstanciado nos direitos fundamentais assegurados pela Constituição" (SILVA, 2019).

defesa que terá um grande trabalho em desconstruir um pré-sentença condenatória (LOPES JR. e RITTER, 2016, pág. 58-59). 
Dessa forma, o juiz das garantias estaria vinculado à fase pré-processual ${ }^{9}$, ou seja, durante o inquérito policial até o recebimento da denúncia, tendo como funções principais o tratamento sobre medidas cautelares diversas da prisão bem como garantindo a observância dos direitos do investigado, conforme dispõe os Art. $3^{\circ}$-A a $3^{\circ}-\mathrm{F}$, em seus incisos e parágrafos do Código de Processo Penal.

O que se verifica em alguns casos é a antecipação da culpabilidade ${ }^{10}$ do agente investigado/acusado, que, por muitas vezes, tem sua liberdade cerceada por prisões cautelares com fundamentos genéricos e respaldada em fundamentações oriundas do inquérito policial, sem a possibilidade do contraditório.

Um exemplo específico da pré-imputação da culpabilidade do agente é vislumbrado nos casos de tráfico de drogas. Uma política caracterizada por uma abordagem desproporcional e ineficaz gera um “[...] desprezo absoluto pela versão de testemunhas de defesa além de mecanismos que privilegiam a inversão do ônus probatório - como a necessidade do próprio réu de fazer a prova diabólica de que a droga apreendida consigo teria exclusivamente a finalidade de consumo" (SEMER, 2019) ${ }^{11}$.

Com isso, dentre as consequências já elencadas em diversas obras, destacam-se, para esse trabalho, o impulsionamento do encarceramento em massa e o empoderamento das facções criminosas, visto que, como apresentado por SEMER (2019), dentre as 800 sentenças

\footnotetext{
${ }^{9} \mathrm{O}$ juiz das garantias, portanto, seria o juiz prevento, entendido como aquele que, em igualdade de competência, tiver antecipado aos outros na prática de algum ato do processo ou de medida a este relativa em momento anterior ao recebimento da denúncia (de acordo com o art. 83 do Código de Processo Penal). Esses atos podem ser "buscas e apreensões, a decretação da prisão preventiva, a homologação da prisão em flagrante e as medidas assecuratórias" (LOPES JR. e RITTER, 2016, pág. 59). No entanto, a prevenção não passa mais a atuar como causa de fixação de competência, mas sim como causa de exclusão da mesma. Nessa medida, o juiz prevento na fase pré-processual não poderá atuar na fase processual, garantindo, portanto, a conservação ao princípio da imparcialidade do juiz.

${ }^{10}$ Para Aury Lopes Jr e Ruiz Ritter (2016, pág. 64), “[...] a prevenção vem dada por um prejulgamento que se realiza no curso da investigação preliminar (como na adoção de medidas cautelares, busca e apreensão, autorização para intervenção telefônica, etc.)".

${ }^{11}$ Importante se faz destacar que a atual legislação específica sobre drogas (a Lei no $11.3434 / 06$ ) é bastante omissa quanto aos critérios objetivos que possam distinguir o crime de posse de drogas para uso (referente ao art. 28 da mencionada Lei) do crime de tráfico de drogas (Art. 33). Logo, cabe primeiro ao agente policial, em sua abordagem e realização do flagrante, estipular qual tipificação se enquadra. Essa seletividade, em muitos casos, é cunhada de estigma social, corroborando para o crescimento da grande massa populacional presente nas penitenciárias brasileiros. Não obstante, os magistrados, ao terem acesso aos Autos de Prisão em Flagrante Delito (APFD), acabam por receber a denúncia (o qual tipifica como tráfico de drogas) e converter a prisão em flagrante em prisão preventiva,com fundamentação em termos genéricos como a conservação da ordem econômica ou social. Logo, o sujeito acusado acaba por passar o processo com restrição de sua liberdade, tendo a probabilidade de ser condenado mediante provas obtidas apenas com depoimento dos policiais que fizeram a abordagem. Ressalta-se que a palavra dos agentes policiais possuem credibilidade, mas a condenação não deve ser baseada apenas nesta.
} 
analisadas, cerca de $90 \%$ dos processos se iniciam com a prisão em flagrante do acusado, causando-lhe a restrição da liberdade.

Embora o instituto se mostre necessário, feita uma análise bibliográfica percebe-se duas ponderações predominantes quanto à inaplicabilidade do juiz das garantias. A primeira corresponderia à desnecessidade do instituto em razão da capacidade dos magistrados em se manterem neutros, não apenas diante dos elementos colhidos na fase pré-processual, mas também em todo o processo, cabendo aos mesmos aplicar o direito ao caso concreto conforme a cognição fundada nas provas obtidas ${ }^{12}$. A segunda ponderação consiste na incapacidade orçamentária do Poder Judiciário de arcar com a formação de concursos e, posteriormente, nomeação de novos juízes, bem como de recursos materiais para abranger a figura de mais um juiz ao rito processual.

Segundo o procurador de Justiça aposentado, Carlos Frederico Coelho Nogueira (2011, $\mathrm{s} / \mathrm{p}$ ), ao apresentar semelhantes argumentos voltados a inviabilidade do instituto do juiz das garantias, argumenta que:

Fôssemos levar às últimas consequências o novo sistema que se quer implantar, teríamos que ter três ou mais juízes no mesmo processo criminal: um no inquérito, outro para decidir sobre o recebimento (ou a rejeição) da denúncia ou da queixa e sobre a absolvição sumária, além de outro para imposição de medidas cautelares, pessoais ou reais, no curso do processo, e, por fim, mais outro, somente para presidir a instrução e proferir a sentença.

Ainda sobre a questão da inviabilidade do instituto, Carlos F. C. Nogueira (Ibidem) reforça que o sistema de juízes de garantias tornaria o processo penal mais burocrático e, possivelmente, violaria o princípio da celeridade processual, podendo ainda gerar alguns embaraços e retardamentos em decisões urgentes e incidentais no decorrer da persecução criminal. Esses problemas poderiam ocasionar num elevado aumento dos casos de prescrição penal e no incremento da impunidade, extinguindo a punibilidade e, por isso, a necessidade de se impor uma pena a uma determinada conduta ilícita.

\footnotetext{
12 Segundo Aury Lopes Jr. e Ruiz Ritter (2016, pág. 64), “[...] o problema é definir se o juiz chamado a atuar no inquérito policial tem condições de proceder ao que se chama de uma ideia sobre a pequena história do processo, sem intensidade suficiente para condicionar, ainda que inconscientemente - e ainda que seja certeiramente - a 'originalidade cognitiva' e condições de efetivo contraditório (que exige condições de 'ouvir' a outra parte em igualdade de condições cognitivas) para que comece e atenue no processo".
} 
No entanto, em relação à primeira ponderação, sustenta-se a parcialidade do juiz, em fase pré-processual, uma vez que, este ao ter acesso aos atos do procedimento investigatório, produzidos em sede do inquérito policial, tem contato com apenas uma narrativa sobre o fato, uma vez que, durante o inquérito policial não existe contraditório, visto que, à parte investigada não é facultado o direito à contradizer o arrolado nos autos do inquérito. Desse modo, verificase, arrogando para si uma função, que em fase ao sistema acusatório não deveria permitir, o Juízo aplicar, antes e/ou durante o transcurso do processo, por exemplo, prisões preventivas de imediato, o que em certa medida, contribui, por consequência, para o engessamento quanto culpabilidade do acusado, violando, assim, o princípio da presunção de inocência.

Quanta a segunda ponderação, o instituto não necessita de nomeações imediatas para magistratura, podendo os juízes de comarcas maiores dividirem-se entre juízes de garantias e juízes de sentença. Outro ponto é que algumas Comarcas, no território brasileiro, são próximas uma das outras. Neste caso, o juiz de uma determinada Comarca A poderia ficar responsável pela fase pré-processual da Comarca B, enquanto o juiz desta Comarca B ficaria responsável pela mesma fase na Comarca A. Isso evitaria, por enquanto, o alto investimento em concursos de magistratura, tendo, apenas, a tarefa do pagamento de diárias aos determinados juízes atuantes em outras Comarcas como juiz das garantias.

Esse instituto, portanto, garantiria uma maior imparcialidade do juiz, bem como fundamentaria um legÍtimo modelo acusatório, somando-se à futura reforma do Código de Processo Penal, bem como à revogação dos dispositivos que possibilitam uma atuação judiciária parcial e ativa do magistrado, proporcionando, assim, um julgamento, sem contaminação pelas narrativas obtidas no inquérito, "podendo, o acusado, ser sentenciado como culpado ou inocente segundo a gestão de provas das partes e o direito ao contraditório e ampla defesa, sem a maculação da jurisdicionalidade" (ALMEIDA, 2019, s/p). Em suma, torna-se evidente que o juiz das garantias tem a possibilidade de garantir, de certo modo, um processo penal mais democrático, assegurando os direitos fundamentais do acusado, bem como a reparação de injustiças.

É necessário frisar que, segundo Ingo Wolfgang Sarlet (In: ROCHA, 2019):

Onde não houver respeito pela vida e pela integridade física e moral do ser humano, onde as condições mínimas para uma existência digna não forem asseguradas, onde não houver limitação de poder, enfim, onde a liberdade a autonomia, a igualdade e os direitos fundamentais não forem reconhecidos e minimamente assegurados, não 
haverá espaço para dignidade humana e a pessoa não passará de mero objeto de arbítrio e injustiças.

Deste modo, é precípua a atuação do Estado no sentido de respeitar o princípio da ultima ratio, bem como garantir, antes de tudo, os direitos fundamentais do agente, neste caso do acusado, antes de segregá-lo e restringi-lo de sua liberdade de modo injusto e sem o devido processo legal.

\section{PONTOS CONTRÁRIOS À IMPLANTAÇÃO DO JUIZ DAS GARANTIAS}

Diante dos fatos elencados acima, bem como o posicionamento de alguns doutrinadores a respeito da necessidade do Juiz das Garantias, percebe-se a enumeração de algumas justificativas legitimante para sua implantação no Processo Penal. Para outros, no entanto, observa-se que o mencionado instituto não deveria ter sua implantação no ordenamento jurídico, devido, entre outros argumentos, a uma inconsistência científica e, possivelmente, uma mera ideologia jurídica. Apresenta-se, portanto, alguns apontamentos contrários à implantação do juiz das garantias no sistema processual penal brasileiro.

Segundo arguiu o Desembargador Federal do Tribunal Regional Federal da $2^{\mathrm{a}}$ Região, Abel Fernandes Gomes (2010), há alguns pontos justificantes do juiz das garantias que devem ser rechaçados. O autor, em sua obra "JUIZ DAS GARANTIAS": inconsistência científica; mera ideologia - como se só juiz já não fosse garantia", apresenta quatro ponderações quanto ao exercício e competência do juiz atuante na fase pré-processual. Esses pontos correspondem a: 1) redundância e rótulo atribuído ao juiz da fase investigatória; 2) da contaminação e distanciamento da questão de mérito atribuído aos juízes; 3 ) da realidade do direito comparado e 4) as consequências em fases recursais. Diante desses pontos, abordaremos brevemente sobre cada um.

Em primeiro lugar, o GOMES (2010), cita a redundância existente e o rótulo atribuído ao juiz da fase pré-processual. "juiz das garantias”, atribuindo à figura uma verdadeira tautologia, empregando um "discurso vicioso, inútil e repetitivo" (2010, pág. 100). Para 
GOMES, a figura do juiz em si, respaldada na Constituição (através do artigo $5^{\circ}$, inciso XXXV), já é garantia dos cidadãos e busca pelos direitos do indivíduo e da coletividade. Assim, sustenta:

[...] a própria figura do juiz, tal como prevista nas leis de organização judiciária, com base na Constituição, já traz em si a garantia ao cidadão de que no processo penal sua função não se há de confundir com a função daquele órgão de outro Poder concebido constitucionalmente para perseguir o fato criminoso, e que por isso, mesmo diante da acusação estatal ou privada a ser deduzida e apurada perante o Poder Judiciário, alguém estará constituído para julgá-lo segundo regras de direito. Nisso o juiz já é garantia (Ibidem, pág. 100).

Complementa ainda Santos (1947, pág. 16 apud GOMES, 2010, pág. 100):

[...] o juiz é aquele que julga ou decide um caso concreto que lhe é apresentado, competindo-lhe dizer o direito aplicável e impor sua observância, o que, como é elementar a tal tarefa, só se perfaz mediante pré-compreensão e enquadramento do caso na norma jurídica adequada, sendo que quem realiza tal tarefa não está comprometido com nenhum dos pontos de vista pugnados pelos interessados.

Portanto, a função do juiz está inteiramente ligada à interpretação e utilização das normas jurídicas, aplicando o direito ao caso concreto. A garantia dos direitos, assim, está ligada ao exercício regular da atividade do magistrado, diante da aplicação legal do direito, considerando a jurisprudência dos Tribunais, bem como os precedentes. A implantação do juiz das garantias, segundo o autor, apenas acomete a atividade do magistrado em um compromisso, excessivo e preferencial, aos interesses individuais do investigado, em qualquer das circunstâncias.

Embora a função da magistratura esteja correta, cabe ressaltar que, na relação processual penal, há apenas direitos para o réu, tendo o Estado apenas o dever de punir diante de uma condenação proveniente de uma sentença penal condenatória transitada em julgado, princípio importante do direito processual penal, correspondente ao princípio da presunção de inocência, consagrado na Carta Magna.

Art. $5^{\circ}$ Todos são iguais perante a lei, sem distinção de qualquer natureza, garantindo-
se aos brasileiros e aos estrangeiros residentes no País a inviolabilidade do direito à
vida, à liberdade, à igualdade, à segurança e à propriedade, nos termos seguintes:
[...] LVII - ninguém será considerado culpado até o trânsito em julgado de sentença
penal condenatória;

Em suma, segundo Aury Lopes Jr. (2018, pág. 96), a presunção de inocência do acusado é o princípio reitor do processo penal, sendo um “[...] dever de tratamento (na medida que exige que o réu seja tratado como inocente), que atua em duas dimensões: interna ao processo e exterior a ele". A dimensão interna se resume à carga probatória, que deve advir da parte 
acusatória e que, na persistência de dúvida de autoria pelo juiz, deve-se conduzir à absolvição do réu (in dubio pro reo). Esses métodos de captação dos fatos impõem, ao magistrado, regras de tratamento e regras de julgamento. Na dimensão externa, "a presunção de inocência exige uma proteção contra a publicidade abusiva e a estigmatização (precoce) do réu" (Ibidem, pág. 97), vinculando-se, portanto, às garantias constitucionais da imagem, da dignidade e da vida privada.

Assim, no processo penal o juiz deve, antes de tudo, zelar pelos direitos do acusado, imputando-lhe sempre o status de inocente até que, pela acusação, se mostre conveniente a autoria e a materialidade do fato criminoso, aplicando-lhe, em decorrência da cognição exauriente, a pena devida.

Alega Gomes (2010), em um segundo momento, a falta de cientificidade para fundamentar o argumento a respeito da contaminação do magistrado diante da análise técnica na fase pré-processual. Segundo o autor, a justificativa elencada para aplicação do juiz das garantias seria que:

[...] o atual sistema, em que o mesmo juiz que decide sobre a admissibilidade, prorrogação e incidentes de medidas investigatórias, meios de coleta de elementos de convicção para oferecimento de denúncia e até mesmo cautelares, em momento anterior àquele em que decidirá o mérito da ação penal à luz das provas carreadas aos autos, acaba por contaminar o julgador [...] (GOMES, 2010, pág. 102).

No entanto, o mesmo reforça que tais assertivas não possuem respaldo em base científica, com a realização de estudos para determinar tais consequências. O autor alega que tais assertivas são a construção “[...] de um juízo daquilo que se imagina difícil, possível, ou provável acontecer" (Ibidem, pág.102).

Consoante a esse argumento, da não cientificidade de tais alegações, o autor ainda indaga a respeito da independência e não contaminação de mais um juiz na hora de analisar os fatos e decidir sobre o recebimento ou não da denúncia, bem como a aplicação de medidas preventivas e protetivas a serem decretadas em fase pré-processual.

Mesmo não apurando o conteúdo material do processo, o juiz das garantias seria decisivo para examinar as circunstâncias do fato apurado e a autorização legal e constitucional para oferecimento da denúncia. Este poderia, em um caso hipotético, ser influenciado pela narrativa do caso e decretar a prisão preventiva do sujeito, diante do não oferecimento de 
medidas diversas da prisão. Neste caso, para que o juiz de sentença revogue tal decisão, teria que analisar os motivos justificantes para tal e, diante desse cenário, ter acesso à denúncia, bem como à fase de inquérito processual.

Assim, GOMES (2010), ainda reflete que alegar um desvio deontológico na figura do magistrado é injusto e infundado, pois:

[...] cientes e conscientes de suas funções, tanto em sede de mero juízo de admissibilidade de meios e medidas provisórias quanto em âmbito de julgamento exaustivo de mérito, e imbuídos e preparados dentro dessa orientação, os juízes brasileiros não estão contaminados ou comprometidos com uma determinada orientação que os faz decidir num determinado sentido, mesmo que desfavorável ao réu, num momento provisório, cautelar ou de apreciação sobre determinada medida probatória, ainda que para isso precisem tangenciar os indícios da existência do fato e da autoria (Ibidem, pág. 104).

Mesmo não havendo base científica justificante, baseando a justificativa em meras suposições, e, possivelmente, diante de análises esparsas (espalhadas) ou escassas (poucas)? de práticas forenses, a instituição do juiz das garantias não inibe que o inconveniente de contaminação do juiz interfira nas decisões fundadas na análise da narrativa do inquérito. Ou seja, a mesma situação que pode corromper, atualmente, a cognição do juiz, criando uma présentença ao acusado em fase pré-processual, pode influenciar a cognição do juiz das garantias, determinando na aplicação de prisões preventivas desnecessárias.

Por fim, GOMES (2010) elenca a questão do direito comparado e a aplicação do juiz das garantias a partir da realidade nacional. Menciona que tal instituto "[...] em nada se compara ao juiz de instrução existente em alguns países" (Ibidem, pág. 104), sendo uma proposição peculiar a ser adaptada ao nosso Direito. Ainda mais, não há trabalhos que demonstrem a efetividade da figura do juiz na fase pré-processual em outros sistemas jurídicos, bem como não há um estudo de impactos da aplicação do juiz das garantias no rito processual penal.

Logo, algumas questões como lotação, princípio da inamovibilidade, a competência segundo o princípio do juiz natural, seriam questões que deveriam ser pensadas e vistas para que, no intuito de garantir melhores condições de julgamento à figura do acusado, não viole princípios básicos do direito processual penal constitucional.

Além do mais, o autor chama atenção às consequências do instituto em vias recursais, questionando que: 
[...] considerando que uma das coisas que se pretende evitar, é que um magistrado que tenha tomado contato com os fatos em grau de juízo de admissibilidade e legitimidade de meios de coleta de elementos prévios de convicção ou medidas cautelares venha ser o mesmo que vá julgar o mérito da ação penal, em caso de desembargadores e ministros das Cortes, Superior e Suprema que venham a conhecer dos habeas corpus impetrados ainda enquanto o processo originário se encontra na fase pré-processual, para discutir a admissibilidade e legitimidade do deferimento de tais medidas pelo juiz das garantias, também se adotará, por coerência e simetria, a instituição dos desembargadores e ministros das garantias, que ficarão impedidos - em vez de preventos - para o julgamento do mérito dos recursos de apelação, especial e extraordinário? (Ibidem, pág. 104).

Algumas dessas ponderações não possuem respostas devido ao instituto ainda não estar em pleno desenvolvimento no cenário processual brasileiro. Outras enfrentam divergências doutrinárias e, devido à inércia legislativa, devem ser resolvidas na órbita das jurisprudências dos Tribunais Superiores, tendo estes que serem provocados para tomada de decisão.

O que é importante ressaltar é que, atualmente, a doutrina se encontra em divergência na questão da atuação dos juízes das garantias e, diante da aprovação da lei no 13.964/2019 pacote anticrime -, tal instituto esteve à beira de sua atividade. No entanto, este foi suspenso, sem prazo, em face à decisão em sede de Medida Cautelar proferida pelo Ministro Relator Luiz Fux, nos autos da Ação Direta de Inconstitucionalidade no(ADI) 6.299 do Distrito Federal (DF), a qual sustentou, entre outros pontos, a necessidade de estudo de impactos voltados à implantação do juiz das garantias.

\section{ANÁlise do INSTITUTO DO JUIZ DE GARANTIAS A PARTIR DA AÇÃo DIRETA DE INCONSTITUCIONALIDADE (ADIN) No 6.299 DF}

Por fim, o presente tópico dedica-se à análise da Ação Direta de Inconstitucionalidade $\mathrm{n}^{\circ}$ 6.299, com pedido de Medida Cautelar proposta perante o Supremo Tribunal Federal (STF), pelo Partido Trabalhista Nacional e outros, contra os arts. $3^{\circ}-\mathrm{A}, 3^{\circ}-\mathrm{B}, 3^{\circ}-\mathrm{C}, 3^{\circ}$-D , $3^{\circ}-\mathrm{E}$ e $3^{\circ}-\mathrm{F}$ (juiz das garantias) e o $\S 5^{\circ}$ do art. 157, inseridos no Código de Processo Penal, por meio da Lei $n^{\circ} 13.964 / 2019$.

Sustentou a parte requerente nos autos da mencionada ação: 1) vício de iniciativa, oportunidade em que arguiu violação ao princípio da separação dos Poderes, como também, a 
cláusula de reserva referente à competência privativa de auto-organização do Judiciário, 2) Falta de Previsão de Impacto Orçamentário e Violação ao novo Regime Fiscal, 3) violação a subprincípios constitucionais elementares da proporcionalidade, quais sejam: adequação, necessidade e proporcionalidade em sentido estrito, 4) violação ao princípio da razoável duração do processo, 5) violação ao pacto federativo, 6) Violação à interpretação conforme a constituição.

Em sede de decisão monocrática proferida nos autos da $\mathrm{ADI}$ n$^{\circ} 6.299$, o então Presidente do STF, Ministro Dias Toffoli, decidiu:

\begin{abstract}
Pelo exposto, ante a urgência de análise liminar, tendo em vista a entrada em vigor da Lei $n^{\circ} 13.964 / 19$ no dia 23 de janeiro de 2020 (art. 20 da lei), concedo parcialmente a medida cautelar pleiteada, ad referendum do Plenário, para: (i) suspender-se a eficácia dos arts. $3^{\circ}$-D, parágrafo único, e $157, \S 5^{\circ}$, do Código de Processo Penal, incluídos pela Lei ${ }^{\circ} 13.964 / 19$; (ii) suspender-se a eficácia dos arts. $3^{\circ}-\mathrm{B}, 3^{\circ}-\mathrm{C}, 3^{\circ}$-D , caput, $3^{\circ}$ E e $3^{\circ}$-F do CPP, inseridos pela Lei $n^{\circ} 13.964 / 2019$, até a efetiva implementação do juiz das garantias pelos tribunais, o que deverá ocorrer no prazo máximo de 180 (cento e oitenta) dias, contados a partir da publicação desta decisão; (iii) conferir-se interpretação conforme às normas relativas ao juiz das garantias (arts. $3^{\circ}-\mathrm{B}$ a $3^{\circ}$-F do $\mathrm{CPP}$ ), para esclarecer que não se aplicam às seguintes situações: (a) processos de competência originária dos tribunais, os quais são regidos pela Lei no ${ }^{\circ}$ 8.038/1990; (b) processos de competência do Tribunal do Júri; (c) casos de violência doméstica e familiar; e (d) processos criminais de competência da Justiça Eleitoral. (iv) fixaremse as seguintes regras de transição: (a) no tocante às ações penais que já tiverem sido instauradas no momento da efetiva implementação do juiz das garantias pelos tribunais (ou quando esgotado o prazo máximo de 180 dias), a eficácia da lei não acarretará qualquer modificação do juízo competente. $O$ fato de o juiz da causa ter atuado na fase investigativa não implicará seu automático impedimento; (b) quanto às investigações que estiverem em curso no momento da efetiva implementação do juiz das garantias pelos tribunais (ou quando esgotado o prazo máximo de 180 dias), o juiz da investigação tornar-se-á o juiz das garantias do caso específico. Nessa hipótese, cessada a competência do juiz das garantias, com o recebimento da denúncia ou queixa, o processo será enviado ao juiz competente para a instrução e o julgamento da causa.
\end{abstract}

Já em sede de reanálise de matéria pelo Ministro Relator Luiz Fux, a respeito da impugnação dos dispositivos relacionados ao juiz das garantias, tomou-se como razões de decidir a "[...] presença dos requisitos do fumus boni iuris e do periculum in mora, determinando a suspensão da eficácia dos artigos $3^{\circ} \mathrm{A}$ a $3^{\circ}-\mathrm{F}$, do Código de Processo Penal, na redação dada pela Lei n. 13.964/2019”.

Além da $\mathrm{ADI}^{\circ}$ 6.299, foram impetradas perante a Suprema Corte outras 03 (três) ações cujo objeto assemelham-se, quais sejam: 1) ADI n. 6.305, ajuizada pela Associação Nacional dos Membros do Ministério Público - CONAMP, impugna os artigos $3^{\circ}$-A; $3^{\circ} \mathrm{B}$, incisos IV, VIII, IX, X e XI; $3^{\circ}$-D, parágrafo único; 28 , caput; 28 -A, incisos III e IV, e $\S \S 5^{\circ}, 7^{\circ}$ e $8^{\circ}$; e 310 , 
$\S 4^{\circ}$, do Código de Processo Penal, todos introduzidos pela Lei n. 13.964/2019, 2) ADI n. 6.298, ajuizada pela Associação dos Magistrados Brasileiros (AMB) e pela Associação dos Juízes Federais do Brasil (AJUFE), impugna a) o artigo $3^{\circ}$ da Lei n. 13.964/2019, que acrescentou os artigos $3^{\circ}-\mathrm{A}, 3^{\circ}-\mathrm{B}, 3^{\circ}-\mathrm{C}, 3^{\circ}-\mathrm{D}, 3^{\circ}-\mathrm{E}$ e $3^{\circ}-\mathrm{F}$ ao Código de Processo Penal e institui a figura do juiz das garantias, e b) o artigo 20 da Lei n. 13.964/2019, que determina o prazo de vacatio legis para a vigência respectiva e 3) ADI n. 6.300, ajuizada pelo Diretório Nacional do Partido Social Liberal (PSL), impugna os artigos $3^{\circ}$-A a $3^{\circ}-\mathrm{F}$ do Código de Processo Penal, na mesma linha das ações anteriores.

As alegações das partes autoras referem-se, em síntese, às inconstitucionalidades formais e materiais vinculadas às competências do Poder Judiciário em organizar e demandar sobre o orçamento judiciário, assim como sustentam que a estipulação do prazo para entrar em vigor tal instituto seria curto, pondo em risco a "segurança jurídica e a instabilidade institucional” (BRASIL, 2020, pág. 11).

\section{CONSIDERAÇÕES FINAIS}

Diante do que foi abordado no trabalho, conclui-se que o processo penal está intrinsecamente relacionado com a pena e com o delito. Importante ressaltar que não há delito sem pena e nem pena sem o delito e sem o processo. Frente a está inter-relação, o processo atua como ferramenta de legitimidade à execução do dever-punir do Estado (imposição da pena), frente a uma situação que apresenta uma justa causa (indícios de autoria e materialidade).

Não obstante, no modelo de Estado Democrático de Direito faz-se necessário um sistema processual que atue na busca pela garantia e proteção dos direitos fundamentais do acusado, tendo a mesmo como parte vulnerável na relação processual, impondo limites na atuação da atividade do Estado. Para isso, é necessário o reforço à imparcialidade da magistratura e a preservação de outros princípios inerentes ao Direito Processual Penal, como o princípio do devido processo legal, da paridade de armas, e de outros princípios relativos ao Direito Penal e Constitucional Penal, como o da presunção de inocência e do contraditório e da ampla defesa, por exemplo. 
Em face de todo o exposto, sustenta-se que a inserção do juiz das garantias no ordenamento jurídico e no processo penal, proporcionará, primeiramente, o reforço de um sistema genuinamente acusatório (em toda a persecução penal), bem como a desvinculação da atuação do magistrado nas duas fases do processo, na qual a primeira consiste na atividade eminentemente acusatória, sem o direito à defesa.

Tais consequências oriundas do instituto do juiz das garantias irá propiciar uma maior segurança aos direitos e garantias fundamentais dos cidadãos (juiz deve atuar como garante dos direitos fundamentais do sujeito passivo), assim como evitará possíveis nulidades processuais e, portanto, produzirá uma maior credibilidade às investigações e ao rito processual penal. Seus benefícios, portanto, proporcionará um processo penal democrático e orientado dentro de prerrogativas constitucionais.

Embora a aplicação do instituto se mostra promissora, é cediço que sua execução no sistema processual brasileiro deve ser realizada de modo eficiente, respeitando um prazo de adaptação (vacatio legis) e de reestruturação das atividades judiciais. No mais, o trabalho não vislumbra esgotar a presente propositura, mas reforça a necessidade da realização de estudos quanto a aplicabilidade do instituto e dos resultados oriundos da práxis jurídica.

\section{REFERÊNCIAS}

ALMEIDA, Thiago Trindade de. O inquérito policial e os resquícios de um sistema acusatório: da necessidade de um juiz das garantias no processo penal brasileiro. Novo Jurista. 06 nov 2019. Disponível em: <https://novojurista.com/2019/11/06/o-inqueritopolicial-e-os-resquicios-de-um-sistema-acusatorio-da-necessidade-de-um-juiz-das-garantiasno-processo-penal-brasileiro/>. Acesso em: 08 mar 2020.

BRASIL. Código de Processo Penal. Decreto-Lei no 3.689, de 3 de outubro de 1941. Brasília/DF. Disponível em:<http://www.planalto.gov.br/ccivil_03/decretolei/del3689compilado.htm>. Acesso em 15 mar. 2020

Senado Federal. Projeto de Lei do Senado no 156, de 2009. Brasília. Disponível em: <https://www25.senado.leg.br/web/atividade/materias/-/materia/90645>. Acesso em 11 mar. 2020. 
.Supremo Tribunal Federal. Ação Direta de Inconstitucionalidade 6.299/DF. Requerente. Partido Trabalhista Nacional e Outro(sa). Rel. Min. Luiz Fux. DF 2020. Disponível em: <https://portal.stf.jus.br/processos/detalhe.asp?incidente=5840373>. Acesso em: 15 mar. 2020

Constituição da República Federativa do Brasil de 1988. Disponível em: <http://www.planalto.gov.br/ccivil_03/constituicao/constituicaocompilado.htm>. Acesso em: 16 mar. 2020.

Lei $N^{\circ} 13.964$, de 24 de Dezembro de 2019. Aperfeiçoa a legislação penal e processual penal. Brasília/DF. Disponível em: $<$ http://www.planalto.gov.br/ccivil_03/_ato20192022/2019/lei/L13964.htm>. Acesso em: 05 mar. 2020.

BUENO DE CARVALHO, Amilton. Lei, Para Que(m)?. In: WUNDERLICH, Alexandre (Coord.). Escritos de Direito e Processo Penal em Homenagem ao Professor Paulo Cláudio Tovo. Rio de Janeiro, Lumen Juris, 2001. p. 56 e s.

GOMES, Abel Fernandes. "JUIZ DAS GARANTIAS": inconsistência científica; mera ideologia - como se só juiz já não fosse garantia. Revista CEJ, Brasília, Ano XIV, n. 51, 2010, p. $98-105$.

LAKATOS, Eva Maria; MARCONI, Marina de Andrade. Fundamentos de metodologia científica. 5. ed. São Paulo: Atlas, 2003.

LOPES JR., Aury. Direito processual penal /Aury Lopes Jr. - 16. ed. - São Paulo: Saraiva educação, 2019.

2018.

Direito processual penal / Aury Lopes Jr. - 15. ed. - São Paulo: Saraiva Educação,

MINAYO, Maria Cecília de Souza (org.). Pesquisa Social: Teoria, método e criatividade. 18 ed. Petrópolis: Vozes, 2001.

NOGUEIRA, Carlos Frederico Coelho. Juiz das garantias do novo CPP é arbitrário. Revista Consultor Jurídico. 06 jun 2011. Disponível em: $<$ https://www.conjur.com.br/2011-jun06/sistema-juiz-garantias-cpp-arbitrario-inviavel>. Acesso em 12 mar. 2020.

ROCHA, Diander. O Estado que fomenta o crime. Canal Ciências Criminais. 26 set. 2019. Disponível em: <https://canalcienciascriminais.com.br/o-estado-que-fomenta-o-crime/>. Acesso em: 07 mar 2020.

SEMER, Marcelo. O papel dos juízes no grande encarceramento: um estudo sobre sentenças de tráfico. Revista Cult. 06 mai. 2019. Disponível em: $<$ https://revistacult.uol.com.br/home/encarceramento-grande-juizes/>. Acesso em: $07 \mathrm{mar}$ 2020.

SILVA, Maycon Maurício Lima. A adoção do juiz das garantias como medida lógica para a proteção dos direitos do acusado. Canal Ciências Criminais. 29 set. 2019. Disponível em: 
$<$ https://canalcienciascriminais.com.br/a-adocao-do-juiz-das-garantias-como-medidalogica/>. Acesso em: 07 mar 2020.

Data de Submissão: 31/03/2020

Data de Aceite: 20/04/2020 